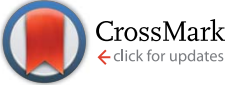

Cite this: RSC Adv., 2017, 7, 16901

\title{
Synthesis of $C_{15}$ and $C_{10}$ fuel precursors with cyclopentanone and furfural derived from hemicellulose $\uparrow$
}

\author{
Wei Wang, ${ }^{\star a b}$ Xiaohui Ji, ${ }^{a}$ Hongguang Ge, ${ }^{a}$ Zhizhou Li, ${ }^{a}$ Guanghui Tian, ${ }^{a}$ \\ Xianzhao Shao ${ }^{a}$ and Qiang Zhang ${ }^{a}$
}

Fuel precursors 2,5-bis(2-furylmethylidene)cyclopentanone $\left(F_{2} C p\right)$ and 2-(2-furylmethylidene) cyclopentanone (FCp) were obtained through aldol condensation of cyclopentanone and furfural over solid acid catalysts under solvent-free conditions. Nafion exhibited the best performance among the investigated catalysts (Nafion, Amberlyst-15, Amberlyst-36, H-USY, ZSM-5, H- $\beta$, and $\mathrm{SiO}_{2} / \mathrm{Al}_{2} \mathrm{O}_{3}$ ). Under optimized conditions, yields of $\mathrm{F}_{2} \mathrm{Cp}$ and $\mathrm{FCp}$ were $37.48 \%$ and $23.77 \%$, respectively. Selectivities of $\mathrm{F}_{2} \mathrm{Cp}$ and FCp were $50.74 \%$ and $32.18 \%$, respectively. Nafion showed good stability and did not deactivate during 4 runs. Meanwhile, a certain amount of humin was also generated during the reaction. The reaction mechanism for the aldol condensation of cyclopentanone and furfural and the formation mechanism of humin were also proposed.

Received 26th February 2017 Accepted 13th March 2017

DOI: $10.1039 / \mathrm{c} 7 \mathrm{ra0} 3396 \mathrm{k}$

rsc.li/rsc-advances
Cyclopentanone can be obtained from a furfural and furfural alcohol selective hydrogenation and rearrangement reaction. ${ }^{24-31}$ Zhang and his group studied selective conversion of furfural to cyclopentanone with CuZnAl catalysts, where the yield obtained was $62 \%{ }^{24}$ Furfural and furfural alcohol selective hydrogenation and rearrangement reaction can be catalyzed with Ni, Pt, Pd, Pt-Ru, and Ru catalysts by using water as the solvent, with a yield of cyclopentanone up to $76.5 \%{ }^{28} \mathrm{Fu}$ et al. reported the selective conversion of furfural to cyclopentanone with $\mathrm{Cu}-\mathrm{Co}$ catalysts with a $67 \%$ yield of cyclopentanone. ${ }^{29} \mathrm{Xu}$ 's group reported conversion of furfural into cyclopentanone over $\mathrm{Ni}-\mathrm{Cu}$ bimetallic catalysts at a $62 \%$ yield. ${ }^{30}$ Xiao et al. reported selective hydrogenation of furfural to cyclopentanone over hydrotalcite-based $\mathrm{Cu}-\mathrm{Ni}-\mathrm{Al}$ catalysts with a yield of up to $95.8 \% .^{31}$

Cyclopentanone can undergo condensation with valeraldehyde, ${ }^{32}$ furfural ${ }^{33,34}$ or itself. ${ }^{35-38}$ It can also react with 2-methyl furan through hydroxyalkylation/alkylation, ${ }^{9,39,40}$ generating $\mathrm{C}_{10^{-}}$ $\mathrm{C}_{15}$ oxygen-containing compounds, and then the $\mathrm{C}_{10}-\mathrm{C}_{15}$ oxygencontaining compounds can be converted into high-density diesel or jet fuel by hydrodeoxygenation. Aldol condensation of cyclopentanone and furfural by sodium hydroxide in solution free system achieved 2,5-bis(2-furylmethylidene)cyclopentanone yield of $96.0 \%{ }^{41}$ Aldol condensation of cyclopentanone and furfural in an aqueous solution of sodium hydroxide gave a 2,5-bis(2furylmethylidene)cyclopentanone yield of more than $95 \% .^{33,34}$ However, the reaction yields a large amount of wastewater and thus was not environmentally benign, additionally, the used sodium hydroxide could not be effectively recycled.

Aldol condensation is an important organic synthetic reaction catalyzed by acid or alkali. It involves transforming of
${ }^{a}$ School of Chemistry and Environment Science, Shaanxi University of Technology, Hanzhong, 723001, China. E-mail: wangwei@snut.edu.cn; Tel: +869162641660 ${ }^{b}$ Shaanxi Key Laboratory of Catalysis, Shaanxi University of Technology, Hanzhong, 723001, China

$\dagger$ Electronic supplementary information (ESI) available. See DOI: $10.1039 / \mathrm{c} 7 \mathrm{ra02396k}$ 
compounds containing active $\alpha$-hydrogen atoms (such as aldehyde, ketone, carboxylic acid, and ester), nucleophilic addition to obtain $\beta$-hydroxyl compounds, and then further dehydration to generate $\alpha, \beta$-unsaturated carbonyl compounds. It could take place in homogeneous aqueous (or water/alcohol) solutions ${ }^{15}$ and biphasic systems. ${ }^{33,42}$ To simplify the process, new solid base catalysts have also been developed. ${ }^{22,43-46}$

In this work, fuel precursors 2,5-bis(2-furylmethylidene) cyclopentanone $\left(\mathrm{F}_{2} \mathrm{Cp}\right)$ and 2-(2-furylmethylidene)cyclopentanone (FCp) were obtained from aldol condensation of cyclopentanone and furfural over solid acids catalyst under solvent-free conditions. Nafion exhibited the best performance among investigated catalysts (Nafion, Amberlyst-15, Amberlyst36, H-USY, ZSM-5, H- $\beta$, and $\mathrm{SiO}_{2} / \mathrm{Al}_{2} \mathrm{O}_{3}$ ). Furthermore, we also studied the effects of catalyst dosage, reaction temperature, and time on the conversion of furfural and yields of $\mathrm{F}_{2} \mathrm{Cp}$ and FCp over the Nafion catalyst under solvent-free conditions. We also investigated the stability of the Nafion catalyst. Finally, the reaction mechanism of aldol condensation of cyclopentanone and furfural and the formation mechanism of humins were also proposed.

\section{Experimental}

\section{Materials}

Nafion resin with a diameter ball of $0.2 \mathrm{~mm}$ was provided by JiangSu Success Resin Ltd. Amberlyst-36 and Amberlyst-15 resins were purchased by Sigma Aldrich. $\mathrm{H}$-USY $\left(\mathrm{SiO}_{2} / \mathrm{Al}_{2} \mathrm{O}_{3}=\right.$ 12), ZSM-5 $\left(\mathrm{SiO}_{2} / \mathrm{Al}_{2} \mathrm{O}_{3}=25\right)$, and $\mathrm{H}-\beta\left(\mathrm{SiO}_{2} / \mathrm{Al}_{2} \mathrm{O}_{3}=25\right)$ zeolites used in this work were provided by Catalyst Factory of Nankai University. $\mathrm{SiO}_{2}-\mathrm{Al}_{2} \mathrm{O}_{3}\left(\mathrm{SiO}_{2} / \mathrm{Al}_{2} \mathrm{O}_{3}=25\right)$ was purchased from Qingdao Ocean Chemical Ltd. Furfural (99\%) and cyclopentanone (99\%) were purchased from Sigma Aldrich. Furfural was purified by vacuum distillation and stored in a refrigerator at $0{ }^{\circ} \mathrm{C} . \mathrm{F}_{2} \mathrm{Cp}$ was prepared following a typical process in the literature. ${ }^{31}$ FCp produced from the reaction of furfural and cyclopentanone was further separated by column chromatography with silica gel (purchased from Merck) as the stationary phase, and a mixture of ethyl acetate and petroleum ether (at a volume ratio of $1: 15)$ was used as the mobile phase. Thin layer chromatography (TLC) was used for detection of FCp, and the collected effluent containing FCp was concentrated through vacuum distillation.

\section{Aldol condensation}

The reactions were carried out in a $50 \mathrm{~mL}$ batch reactor with a reflex condenser and a magnetic stirrer at atmospheric pressure. The temperature was controlled by a pre-heated oil bath. In a typical reaction, $0.40 \mathrm{~g}$ of catalyst, $1.92 \mathrm{~g}$ of furfural (20 $\mathrm{mmol})$, and $5.04 \mathrm{~g}$ of cyclopentanone $(60 \mathrm{mmol})$ were added to the reactor and then the mixture was stirred at $60^{\circ} \mathrm{C}$ for $6 \mathrm{~h}$.

\section{Separation of humins}

The crude product in the reactions was then mixed with $200 \mathrm{~mL}$ of anhydrous ethanol under refluxing for $30 \mathrm{~min}$. Unreacted furfural, cyclopentanone, and the products of FCp and $\mathrm{F}_{2} \mathrm{Cp}$ were separated from insoluble residue through filtering at a high temperature $\left(\sim 78{ }^{\circ} \mathrm{C}\right)$. The residue was treated twice with $200 \mathrm{~mL}$ of anhydrous ethanol to completely removed the soluble substances. The residue solid was humins.

\section{Analysis}

The concentrations of $\mathrm{F}_{2} \mathrm{Cp}$, FCp, and furfural were determined by an Agilent 1260 high performance liquid chromatography (HPLC) system, equipped with a ZORBAXSB-C ${ }_{18}$ column $(4.6 \mathrm{~mm} \times 150 \mathrm{~mm}, 5 \mu \mathrm{m})$ and a refractive index detector (RID). A solution of methanol and water $(9: 1 \mathrm{v} / \mathrm{v})$ was used as the eluent.

The products were verified with a Bruker AVANCE $500 \mathrm{MHz}$ NMR spectrometer, with chloroform-d (99.8\% atom D with $0.1 \% \mathrm{v} / \mathrm{v}$ tetramethylsilane (TMS)) from Aldrich was used as the solvent for ${ }^{1} \mathrm{H}$ and ${ }^{13} \mathrm{C}$ NMR sample preparation. Chemical shifts, quoted in ppm, are relative to the internal standards of the singlet at $\delta=0 \mathrm{ppm}$ for TMS for ${ }^{1} \mathrm{H}$ NMR and the middle peak of the $\mathrm{CDCl}_{3}$ triplet at $\delta=77 \mathrm{ppm}$ for ${ }^{13} \mathrm{C} \mathrm{NMR}$.

Infrared (IR) spectra were measured with a Bruker Vertex 70 Infrared spectrometer using a pressed disc method with potassium bromide. The instrumental resolution was set to at 4 $\mathrm{cm}^{-1}$. The IR spectrum of air was recorded as the background, and then samples were placed in a holder for transmittance measuring. Scan time of $60 \mathrm{~s}$ were used for both the background and the samples.

The conversions of furfural and the yields of $\mathrm{F}_{2} \mathrm{Cp}$ and FCp were calculated by the following formulas:

$$
\begin{aligned}
\text { Conversions of furfural }(\%)= & \frac{\text { moles of furfural consumed }}{\text { moles of furfural input }} \\
& \times 100 \%
\end{aligned}
$$

$$
\text { Yield of FCp }(\%)=\frac{\text { moles of FCp }}{\text { moles of furfural input }} \times 100 \%
$$

Yield of $\mathrm{F}_{2} \mathrm{Cp}(\%)=\frac{2 \times \text { moles of } \mathrm{F}_{2} \mathrm{Cp}}{\text { moles of furfural input }} \times 100 \%$

\section{Results and discussion}

\section{Aldol condensation of furfural with cyclopentanone}

The aldol condensation of furfural with cyclopentanone was carried out over solid acid catalysts. According to the analysis of HPLC (p S2 in ESI $\dagger$ ) and NMR (p S3, S4 in ESI $\dagger$ ) spectra, $\mathrm{F}_{2} \mathrm{Cp}$ (in Scheme 1) was identified as the main product. In addition, FCp (in Scheme 1) was also detected in the reaction mixture. As shown in Scheme 1, FCp was the product of the aldol condensation of furfural with cyclopentanone, and $\mathrm{F}_{2} \mathrm{Cp}$ was the product of aldol condensation between FCp further with furfural. The NMR spectra (p S3 in ESI $\dagger$ ) of $\mathrm{F}_{2} \mathrm{Cp}$ show the following peaks: ${ }^{1} \mathrm{H} \mathrm{NMR}\left(\mathrm{CDCl}_{3}-\mathrm{d}\right), \delta: 7.80(\mathrm{~s}, 2 \mathrm{H}), 7.56(\mathrm{~s}, 2 \mathrm{H})$, $6.90(\mathrm{t}, 2 \mathrm{H}), 6.75(\mathrm{~m}, 2 \mathrm{H}), 3.28(\mathrm{t}, 4 \mathrm{H}) ;{ }^{13} \mathrm{C} \mathrm{NMR}\left(\mathrm{CDCl}_{3}-\mathrm{d}\right), \delta: 195$ (1C), 152 (2C), 144 (2C), 135 (2C), 119 (2C), 116 (2C), 112 (2C), 

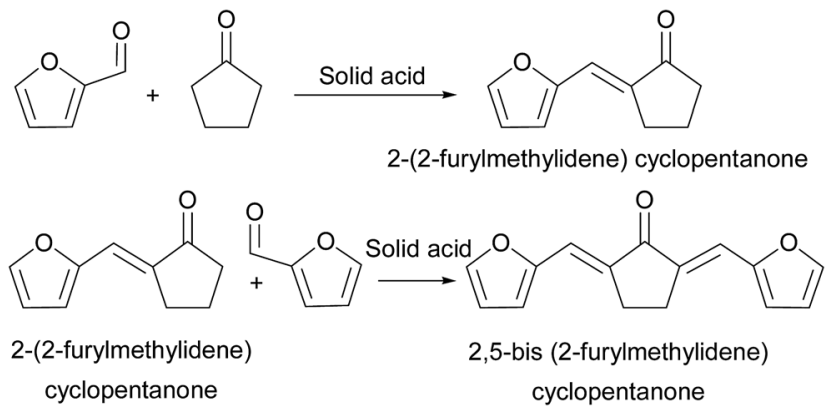

Scheme 1 Reaction route of aldol condensation of furfural and cyclopentanone.

25 (2C). The $\mathrm{F}_{2} \mathrm{Cp}$ obtained was in the form of yellow needles crystal. The NMR spectra (p S4 in ESI $\dagger$ ) of FCp show the following peaks: ${ }^{1} \mathrm{H}$ NMR $\left(\mathrm{CDCl}_{3}\right.$-d), $\delta: 7.71(\mathrm{~s}, 1 \mathrm{H}), 7.37(\mathrm{~d}, 1 \mathrm{H}, J$ $=4), 6.87(\mathrm{t}, 1 \mathrm{H}), 6.72(\mathrm{~d}, 1 \mathrm{H}, J=4), 3.20(\mathrm{t}, 2 \mathrm{H}), 2.59(\mathrm{t}, 2 \mathrm{H}), 2.26$ $(\mathrm{m}, 2 \mathrm{H}) ;{ }^{13} \mathrm{C} \mathrm{NMR}\left(\mathrm{CDCl}_{3}\right.$-d), $\delta: 207$ (1C), 152 (1C), 144 (1C), 133 (1C), 118 (1C), 115 (1C), 112 (1C), 37 (1C), 28 (1C), 19 (1C). The FCp was a yellow-brown solid.

The catalytic performances of different solid acids for the aldol condensation of furfural with cyclopentanone are shown Fig. 1, which shows that solid acid catalysts can promote the aldol condensation of furfural with cyclopentanone. Higher yields of $\mathrm{F}_{2} \mathrm{Cp}$ and $\mathrm{FCp}$ could be achieved over Nafion, Amberlyst-15, and Amberlyst-36 resins than under catalysis by $\mathrm{H}$-USY, HZSM-5, H- $\beta, \mathrm{SiO}_{2} / \mathrm{AlO}_{3}$ under the same reaction conditions.

The sequence for the yield of $\mathrm{F}_{2} \mathrm{Cp}$, FCp over the solid acid catalysts was Nafion $>$ Amberlyst-15 > Amberlyst-36 > H- $\beta, \mathrm{H}-$ USY, ZSM-5, $\mathrm{SiO}_{2} / \mathrm{Al}_{2} \mathrm{O}_{3}$. This sequence is consistent with that of the Hammett acidity function $\left(-H_{\mathrm{o}}\right)$ values of these catalysts (see Table 1). Therefore, the higher catalytic efficiency of Nafion resin can be attributed to the higher strength of acid sites on this catalyst. The higher acid strength of Nafion resin is dependent on by its structure. As we know, Nafion is

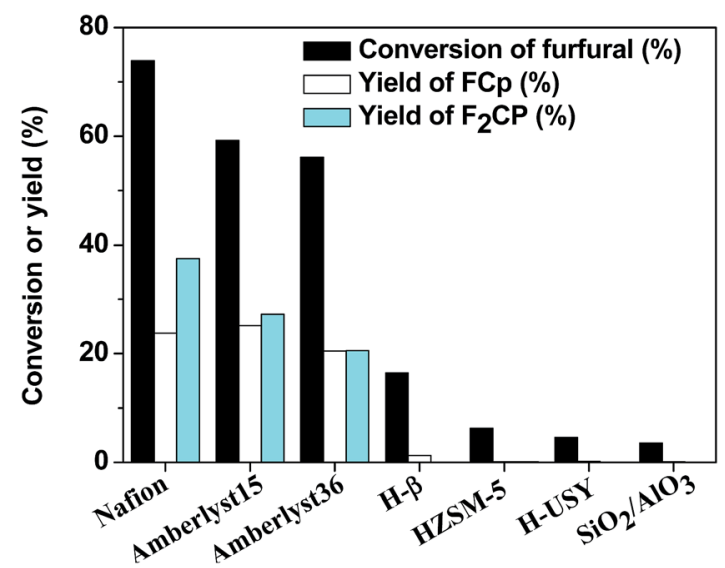

Fig. 1 The aldol condensation of furfural and cyclopentanone over various heterogeneous catalysts. Reaction conditions: $60{ }^{\circ} \mathrm{C}, 6 \mathrm{~h}$; $1.92 \mathrm{~g}(20 \mathrm{mmol})$ furfural, $5.04 \mathrm{~g}(60 \mathrm{mmol})$ cyclopentanone, $0.40 \mathrm{~g}$ catalyst.
Table 1 Average pore sizes, acid amounts and Hammett acidity function $\left(-H_{0}\right)$ values of the different solid acid catalysts used in the aldol condensation of furfural and cyclopentanone ${ }^{a}$

\begin{tabular}{|c|c|c|c|}
\hline Catalyst & $\begin{array}{l}\text { Acid amount } \\
\left(\mathrm{mmol} \mathrm{g}^{-1}\right)\end{array}$ & $\begin{array}{l}\text { Average } \\
\text { pore size }(\mathrm{nm})\end{array}$ & $-H_{\mathrm{o}}$ \\
\hline Nafion & 3.0 & 4.0 & 11-13 (ref. 45) \\
\hline Amberlyst-15 & 4.7 & 29 & 2.2 (ref. 49) \\
\hline Amberlyst-36 & 5.4 & 24 & $2.2-2.65$ (ref. 50) \\
\hline H-ZSM-5 & 0.43 & 0.5 & 5.6-5.7 (ref. 50) \\
\hline H-USY & $0.44-0.48$ & 0.7 & $3.0-4.4$ (ref. 50) \\
\hline $\mathrm{H}-\beta$ & 0.2 & $\begin{array}{l}0.6 \times 0.67 \\
0.56 \times 0.56\end{array}$ & 4.4-5.7 (ref. 49) \\
\hline $\mathrm{H}-\mathrm{Y}$ & 0.9 & $0.74 \times 0.74$ & -1.5 to 5.6 (ref. 49$)$ \\
\hline
\end{tabular}

a perfluorinated sulfonic acid resin, ${ }^{47}$ while Amberlyst resins are sulfonic-acid-functionalized cross-linked polystyrene. ${ }^{48}$ The presence of fluorine on the Nafion resin greatly enhances the acid strength of the $-\mathrm{SO}_{3} \mathrm{H}$ group.

The influence of catalyst dosage on aldol condensation of furfural and cyclopentanone is shown in Fig. 2. It can be seen that conversion of furfural was increased as the amount of catalyst was raised from 0.2 to $0.5 \mathrm{~g}$. Meanwhile, yields of $\mathrm{F}_{2} \mathrm{Cp}$ and FCp increased with the catalyst dosage first, and then leveled off. When the catalyst amount of $0.40 \mathrm{~g}$, yields of $\mathrm{F}_{2} \mathrm{Cp}$ and FCp maximized. Hence, the catalyst amount was $0.40 \mathrm{~g}$ in the following parts.

Temperature is an important parameter for any chemical reaction. Thus, the effect of the reaction temperature on the conversion of furfural, yields of $\mathrm{F}_{2} \mathrm{Cp}$ and FCp were studied and the results were shown in Fig. 3. The conversion of furfural increased first, and then remained constant as the reaction temperature increased further. Moreover, yields of $\mathrm{F}_{2} \mathrm{Cp}$ and FCp increased at first with the reaction temperature, and then decreased. Therefore, the chosen reaction temperature was $60{ }^{\circ} \mathrm{C}$.

The impact of reaction time on the conversion of furfural, yields of $\mathrm{F}_{2} \mathrm{Cp}$ and FCp was then examined. The experimental

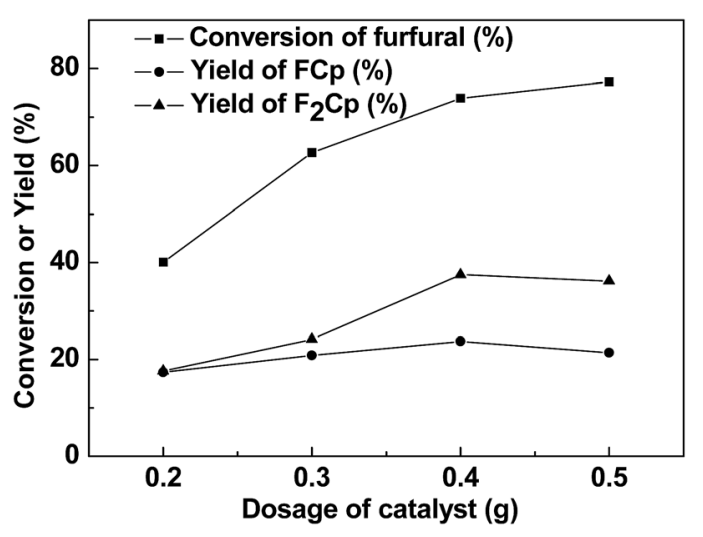

Fig. 2 The effect of the catalyst dosage on the aldol condensation. Reaction conditions: $60{ }^{\circ} \mathrm{C}, 6 \mathrm{~h} ; 1.92 \mathrm{~g} \mathrm{(20} \mathrm{mmol)} \mathrm{furfural,} 5.04 \mathrm{~g} \mathrm{(60}$ $\mathrm{mmol}$ ) cyclopentanone. 


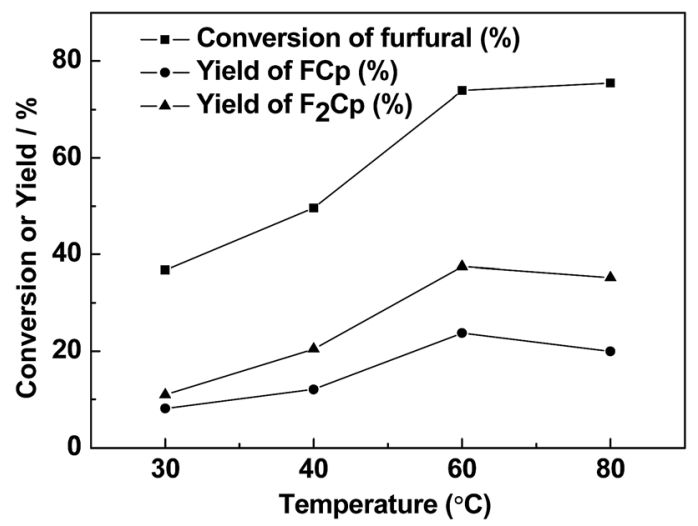

Fig. 3 The effect of reaction temperature on the aldol condensation. Reaction conditions: $0.40 \mathrm{~g}$ Nafion catalyst, $6 \mathrm{~h} ; 1.92 \mathrm{~g}(20 \mathrm{mmol})$ furfural, $5.04 \mathrm{~g}(60 \mathrm{mmol})$ cyclopentanone.

results were shown in Fig. 4 . It can be seen that conversion of furfural first increased and then remained constant as the reaction time was prolonged from 0.5 to 8 hours. The conversion of furfural was $73.86 \%$ at $6 \mathrm{~h}$. Meanwhile, yields of $\mathrm{F}_{2} \mathrm{Cp}$ and FCp increased at first, and then remained constant. At $6 \mathrm{~h}$, yields of $\mathrm{F}_{2} \mathrm{Cp}$ and $\mathrm{FCp}$ were $37.48 \%$ and $23.77 \%$, respectively. Thus, the reaction time of $6 \mathrm{~h}$ was better.

The stability of Nafion in the aldol condensation of furfural and cyclopentanone was implemented. To eliminate the influence of residues, the catalysts were regenerated with a $10 \%$ $\mathrm{H}_{2} \mathrm{O}_{2}$ aqueous solution at $80^{\circ} \mathrm{C}$ for $2.0 \mathrm{~h}$. Then, the mixture was filtered and the catalyst was dried at $80{ }^{\circ} \mathrm{C}$ for $2.0 \mathrm{~h}$ after each usage. According to the results shown in Fig. 5, Nafion showed good stability in the aldol condensation of furfural and cyclopentanone. No evident activity change was noticed over this catalyst after it was used 4 times. Considering the excellent catalytic performance and good stability of Nafion resin, we consider it a promising catalyst in future applications.

Under the optimum conditions $\left(60^{\circ} \mathrm{C}, 6\right.$ hours, and $0.40 \mathrm{~g}$ catalyst), aldol condensation of furfural and cyclopentanone on Nafion catalyst in solvent-free conditions gave a conversion of

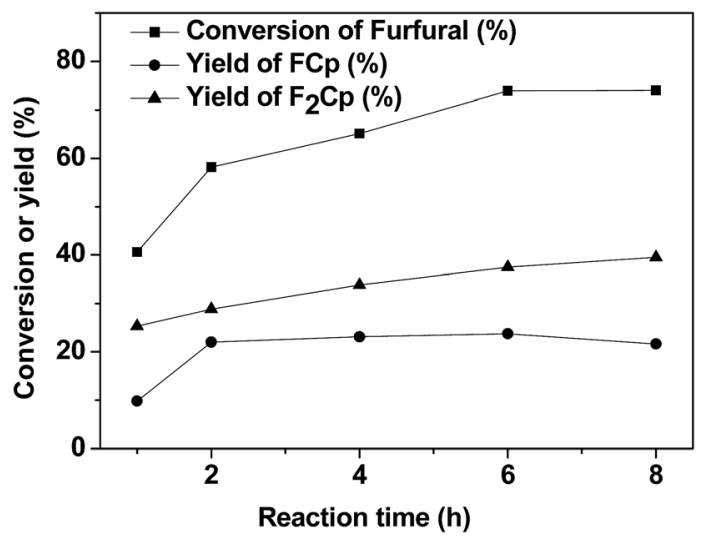

Fig. 4 The effect of reaction time on the aldol condensation. Reaction conditions: $0.40 \mathrm{~g}$ Nafion catalyst, $1.92 \mathrm{~g}(20 \mathrm{mmol})$ furfural, $5.04 \mathrm{~g}$ (60 $\mathrm{mmol}$ ) cyclopentanone at $60^{\circ} \mathrm{C}$.

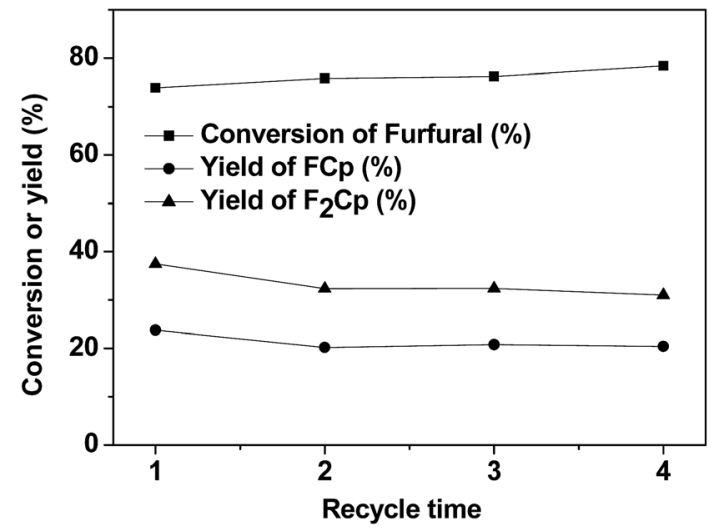

Fig. 5 The recyclability of Nafion resin for the aldol condensation. Reaction conditions: $60{ }^{\circ} \mathrm{C}, 6 \mathrm{~h} ; 1.92 \mathrm{~g} \mathrm{(20} \mathrm{mmol)} \mathrm{furfural,} 5.04 \mathrm{~g}$ (60 $\mathrm{mmol}$ ) cyclopentanone, and $0.40 \mathrm{~g}$ of Nafion.

$73.86 \%$ for furfural and yields of $37.48 \%$ and $23.77 \%$ for $\mathrm{F}_{2} \mathrm{Cp}$ and FCp, respectively. Selectivities of $\mathrm{F}_{2} \mathrm{Cp}$ and $\mathrm{FCp}$ were $50.74 \%$ and $32.18 \%$, respectively.

\section{Reaction mechanism of furfural with cyclopentanone}

The reaction mechanism of aldol condensation using furfural and cyclopentanone by solid acid catalysis is shown in Scheme 2. Cyclopentanone is first protonated by a proton $\left(\mathrm{H}^{+}\right)$ over solid acid to form an electron-deficient intermediate (1). The $\pi$ electron of $\mathrm{C}=\mathrm{O}$ double bonds is transferred to the electron-deficient atom of oxygen to form carbocation (2). Carbanion and $\mathrm{H}^{+}$were gained by electron heterolytic formation of alpha $\mathrm{C}-\mathrm{H} \sigma$ bond of carbocation. The lone pair electrons of the carbanion are split and transfer to the carbocation, and the $\mathrm{C}=\mathrm{C}$ bond-containing enol structure (3) is formed. The negatively charged carbon of (3) attacked the $\mathrm{C}$ atom of $\mathrm{C}=\mathrm{O}$ of the same protonated furfural. The $\pi$ electron of intermediate (4) is

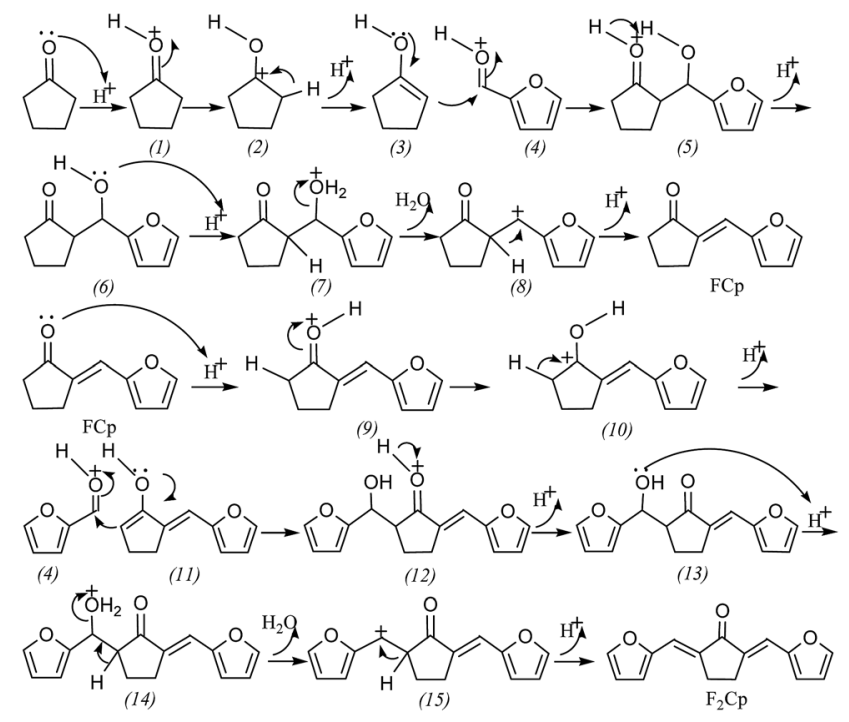

Scheme 2 Reaction mechanism of aldol condensation from furfural and cyclopentanone by solid acid catalysis. 
transferred to the electron-deficient oxygen of carbonyl. At the same time, the $\mathrm{C}=\mathrm{C} \pi$ electrons of intermediate (3) attack the electron-deficient carbon of intermediate (4) to form a $\mathrm{C}-\mathrm{C}$ bond and the lone pair on the oxygen atom transferred to the adjacent carbon atoms to form $\mathrm{C}=\mathrm{C}$ gave rise to the structure of the intermediate (5). The intermediate (5) released protons to form intermediate (6). Hydroxyl groups of intermediate (6) are protonated to form intermediate (7) under acidic conditions. Then, one molecule of water is released to form intermediate (8). Meanwhile, the $\mathrm{C}-\mathrm{H} \sigma$ bond is transferred and proton is released to form the product FCp.

The carbonyl of FCp is protonated to obtain intermediate (9), and the $\pi$ electron of $\mathrm{C}=\mathrm{O}$ in intermediate (9) transferred to the carbonyl oxygen atom to form a carbon cationic structure (10), which undergoes heterolytic electron transfer to form the enol structure (11). The negative charge of the carbon with a protonated enol structure (11) attacks the protonated carbonyl of furfural in intermediate (4), forming a C-C bond to obtain the intermediate (12). Intermediate (12) releases proton and forms intermediate (13). The intermediate (13) is protonated to form intermediate (14), and then releases a water molecule to form intermediate (15) ( $\sigma$ bond shift). At the same time, proton is removed to form the product $\mathrm{F}_{2} \mathrm{Cp}$. This reaction mechanism is similar to that of acetophenone and benzaldehyde under the catalysis of sulfuric acid. ${ }^{51}$

\section{Formation mechanism of humins}

Water is continuously produced from aldol condensation of furfural and cyclopentanone on solid acid conditions. Under these conditions, furfural can be easily polymerized through hydrolysis. The conversion process is shown in Scheme 3. Furfural is first hydrolyzed to produce 5-hydroxy-4,5-dihydrofuran-2carbaldehyde (I) or 2-hydroxy-2,3-dihydrofuran-2-carbaldehyde (II). The hydrolysis mechanism of furfural is similar to that of 5hydroxymethyl furfural..$^{52-54}$ The open ring of intermediates I and II generate 2-oxo pentanedial (III). Isomerization and rearrangement of intermediate III provided 4-hydroxy-5-oxo-4-pentene aldehyde (IV), 2-hydroxy-2-ene glutaraldehyde (V), or 5-hydroxy-2oxo-4-aldehyde (VI). Then the aldol condensation of IV, V, and VI with furfural forms 4,5-dioxo-6-hydroxy-6-tetrahydrofuran hexanal (VII), 2-oxo-3-tetrahydrofuran methylene pentanedial (VIII), and 2-oxo-4-tetrahydrofuran methylene pentanedial (IX). VII, VIII, and IX will polymerize by themselves or interaction each other to form a polymer with high viscosity (humins). The humins can easily cover the catalyst surface form a membrane. Leading to the active centers of the catalyst are completely isolated from the feedstock (cyclopentanone and furfural). The catalyst subsequently will loss of activity, and therefore the reaction cannot complete thoroughly. Intermediate III can also generate humins through self-condensation or condensation with furfural. This is the reason why, under the optimized conditions, conversion of furfural was $73.86 \%$ and the yields of $\mathrm{F}_{2} \mathrm{Cp}$ and FCp were $37.48 \%$ and $23.77 \%$, respectively. Selectivities of $\mathrm{F}_{2} \mathrm{Cp}$ and $\mathrm{FCp}$ were $50.74 \%$ and $32.18 \%$, respectively. At the same time, we also found that, during the regeneration process of the catalyst, a layer of thin

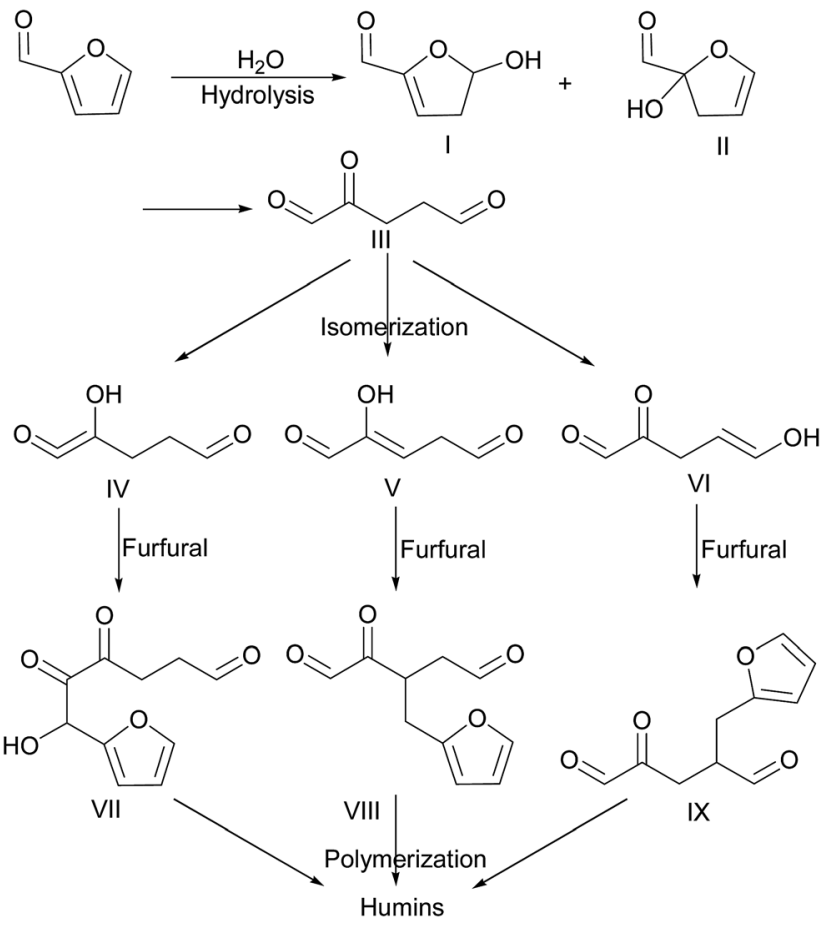

Scheme 3 Formation mechanism of humins.

film formed on the surface of the Nafion ball. It is consistent with formation polymer of hydrolysis reaction.

The infrared spectrum of the polymer is shown in Fig. 6. The weak absorption at $3134 \mathrm{~cm}^{-1}$ and $3115 \mathrm{~cm}^{-1}$ belong to the $\mathrm{C}-\mathrm{H}$ bond stretching vibration of the furan ring. The weak absorption bands at $2877-2957 \mathrm{~cm}^{-1}$ are attributed to $\mathrm{CH}_{2}$ bond stretching vibration owing to polymerization. The weak absorption peak at $1735 \mathrm{~cm}^{-1}$ is due to the stretching vibration of the $\mathrm{C}=\mathrm{O}$ bonds in aldehyde groups. The strong absorption peaks at $1707 \mathrm{~cm}^{-1}$ and $1681 \mathrm{~cm}^{-1}$ are caused by the stretching vibration of $\mathrm{C}=\mathrm{O}$ bonds in unsaturated aldehyde and ketone. The strong absorption peaks at $1622 \mathrm{~cm}^{-1}$ and $1604 \mathrm{~cm}^{-1}$ correspond to the $\mathrm{C}=\mathrm{C}$ stretching vibration and those at 1473 $\mathrm{cm}^{-1}, 1388 \mathrm{~cm}^{-1}$, and $1348 \mathrm{~cm}^{-1}$ are attributed to the $\mathrm{C}-\mathrm{H}$

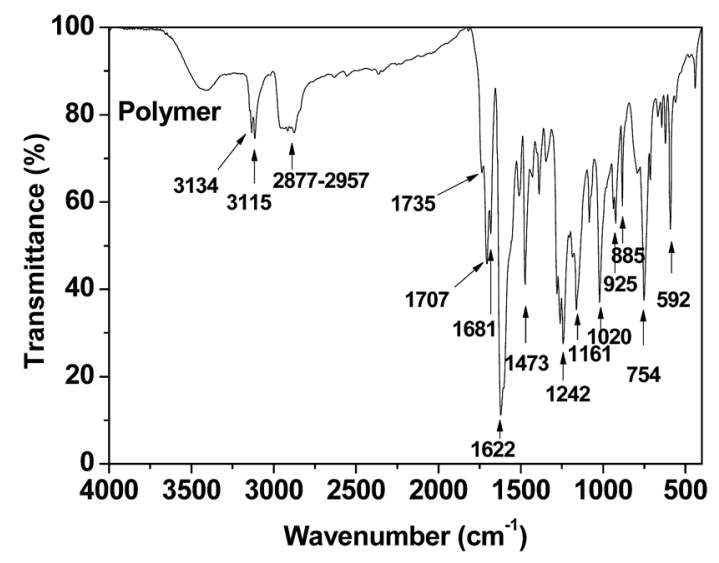

Fig. 6 Infrared spectra of furfural polymers. 
bending vibrations in $\mathrm{CH}_{2}$ bonds. Absorption peaks at 1280 $\mathrm{cm}^{-1}, 1261 \mathrm{~cm}^{-1}, 1205 \mathrm{~cm}^{-1}$, and $1161 \mathrm{~cm}^{-1}$ corresponded to $\mathrm{C}-\mathrm{O}$ bond stretching vibrations, while those at $3134 \mathrm{~cm}^{-1}$, $3115 \mathrm{~cm}^{-1}, 1622 \mathrm{~cm}^{-1}, 1604 \mathrm{~cm}^{-1}, 1485 \mathrm{~cm}^{-1}, 1161 \mathrm{~cm}^{-1}$, $1020 \mathrm{~cm}^{-1}, 754 \mathrm{~cm}^{-1}$, and $592 \mathrm{~cm}^{-1}$ are caused by the vibrations of the furan ring.

\section{Conclusions}

A series of solid acid catalysts were firstly used for the synthesis of fuel precursors $\mathrm{F}_{2} \mathrm{Cp}$ and $\mathrm{FCp}$ from cyclopentanone and furfural derived from hemicellulose in a solvent free system. Nafion exhibited the best performance among the investigated catalysts (Nafion, Amberlyst-15, Amberlyst-36, H-USY, ZSM-5, H$\left.\beta, \mathrm{SiO}_{2} / \mathrm{Al}_{2} \mathrm{O}_{3}\right)$. The effects of dosage of catalyst, reaction temperature, and time are studied. Under the optimized conditions, conversion of furfural was $73.86 \%$, the yields of $\mathrm{F}_{2} \mathrm{Cp}$ and $\mathrm{FCp}$ were $37.48 \%$ and $23.77 \%$, respectively. No deactivation was observed during 4 continuous runs. Mechanism of aldol condensation of furfural and cyclopentanone was proposed in detail. Meanwhile, a certain amount of humins also formed in the reaction process, and the products were characterized using FT-IR spectra.

\section{Acknowledgements}

This study was supported by the Education Department of Shaanxi Provincial Government Research Project (No. 16JK1146), the National Natural Science Foundation of China (No. 21503125, 21502109), and the Funds of Research Programs of Shaanxi University of Technology (No. SLGQD13(2)-1).

\section{Notes and references}

1 G. W. Huber and A. Corma, Chem. Rev., 2006, 106, 40444098.

2 C. Zhao, Y. Kou, A. A. Lemonidou, X. Li and J. A. Lercher, Angew. Chem., Int. Ed., 2009, 48, 3987-3990.

3 D. M. Alonso, J. Q. Bond, J. C. Serrano-Ruiz and J. A. Dumesic, Green Chem., 2010, 12, 992-999.

4 M. J. Climent, A. Corma and S. Iborra, Green Chem., 2014, 16, 516-547.

5 C. Zhao and J. A. Lercher, Angew. Chem., Int. Ed., 2012, 51, 5935-5940.

6 T. D. Matson, K. Barta, A. V. Iretskii and P. C. Ford, J. Am. Chem. Soc., 2011, 133, 14090-14097.

7 S. Li, N. Li, G. Li, A. Wang, Y. Cong, X. Wang and T. Zhang, Catal. Today, 2014, 234, 91-99.

8 G. Li, N. Li, S. Li, A. Wang, Y. Cong, X. Wang and T. Zhang, Chem. Commun., 2013, 49, 5727-5729.

9 G. Li, N. Li, X. Wang, X. Sheng, S. Li, A. Wang, Y. Cong, X. Wang and T. Zhang, Energy Fuels, 2014, 28, 5112-5118.

10 G. Nie, X. Zhang, P. Han, J. Xie, L. Pan, L. Wang and J.-J. Zou, Chem. Eng. Sci., 2017, 158, 64-69.

11 J. Q. Bond, D. M. Alonso, D. Wang, R. M. West and J. A. Dumesic, Science, 2010, 327, 1110-1114.
12 D. A. S. Edward, L. Kunkes, R. M. West, J. C. Serrano-Ruiz, C. A. Gärtner and J. A. Dumesic, Science, 2008, 322, 417-421.

13 G. W. Huber, J. N. Chheda, C. J. Barrett and J. A. Dumesic, Science, 2005, 308, 1446-1450.

14 H. Olcay, A. V. Subrahmanyam, R. Xing, J. Lajoie, J. A. Dumesic and G. W. Huber, Energy Environ. Sci., 2013, 6, 205-216.

15 R. Xing, A. V. Subrahmanyam, H. Olcay, W. Qi, G. P. van Walsum, H. Pendse and G. W. Huber, Green Chem., 2010, 12, 1933-1946.

16 I. Agirrezabal-Telleria, J. Requies, M. B. Güemez and P. L. Arias, Appl. Catal., B, 2012, 115-116, 169-178.

17 P. Azadi, R. Carrasquillo-Flores, Y. J. Pagán-Torres, E. I. Gürbüz, R. Farnood and J. A. Dumesic, Green Chem., 2012, 14, 1573-1576.

18 E. I. Gürbüz, S. G. Wettstein and J. A. Dumesic, ChemSusChem, 2012, 5, 383-387.

19 Q. N. Xia, Q. Cuan, X. H. Liu, X. Q. Gong, G. Z. Lu and Y. Q. Wang, Angew. Chem., Int. Ed., 2014, 53, 9755-9760.

20 W. Shen, G. A. Tompsett, K. D. Hammond, R. Xing, F. Dogan, C. P. Grey, W. C. Conner, S. M. Auerbach and G. W. Huber, Appl. Catal., A, 2011, 392, 57-68.

21 R. M. West, Z. Y. Liu, M. Peter, C. A. Gärtner and J. A. Dumesic, J. Mol. Catal. A: Chem., 2008, 296, 18-27.

22 M. Chatterjee, K. Matsushima, Y. Ikushima, M. Sato, T. Yokoyama, H. Kawanami and T. Suzuki, Green Chem., 2010, 12, 779-782.

23 G. Li, N. Li, Z. Wang, C. Li, A. Wang, X. Wang, Y. Cong and T. Zhang, ChemSusChem, 2012, 5, 1958-1966.

24 J. Guo, G. Xu, Z. Han, Y. Zhang, Y. Fu and Q. Guo, ACS Sustainable Chem. Eng., 2014, 2, 2259-2266.

25 M. Hronec, K. Fulajtarová and T. Liptaj, Appl. Catal., A, 2012, 437-438, 104-111.

26 M. Hronec, K. Fulajtárova and M. Mičušik, Appl. Catal., A, 2013, 468, 426-431.

27 M. Hronec, K. Fulajtárová, I. Vávra, T. Soták, E. Dobročka and M. Mičušík, Appl. Catal., B, 2016, 181, 210-219.

28 M. Hronec and K. Fulajtarová, Catal. Commun., 2012, 24, 100-104.

29 X.-Y. Li, R. Shang, M.-C. Fu and Y. Fu, Green Chem., 2015, 17, 2790-2793.

30 Y. Yang, Z. Du, Y. Huang, F. Lu, F. Wang, J. Gao and J. Xu, Green Chem., 2013, 15, 1932-1940.

31 H. Zhu, M. Zhou, Z. Zeng, G. Xiao and R. Xiao, Korean J. Chem. Eng., 2014, 31, 593-597.

32 M. Hasni, G. Prado, J. Rouchaud, P. Grange, M. Devillers and S. Delsarte, J. Mol. Catal. A: Chem., 2006, 247, 116-123.

33 M. Hronec, K. Fulajtárova, T. Liptaj, M. Štolcová, N. Prónayová and T. Soták, Biomass Bioenergy, 2014, 63, 291-299.

34 M. Hronec, K. Fulajtárova, T. Liptaj, N. Prónayová and T. Soták, Fuel Process. Technol., 2015, 138, 564-569.

35 J. Yang, N. Li, G. Li, W. Wang, A. Wang, X. Wang, Y. Cong and T. Zhang, Chem. Commun., 2014, 50, 2572-2574.

36 X. Sheng, N. Li, G. Li, W. Wang, J. Yang, Y. Cong, A. Wang, X. Wang and T. Zhang, Sci. Rep., 2015, 5, 9565. 
37 W. Wang, N. Li, G. Li, S. Li, W. Wang, A. Wang, Y. Cong, X. Wang and T. Zhang, ACS Sustainable Chem. Eng., 2017, 5, 1812-1817.

38 Q. Deng, G. Nie, L. Pan, J.-J. Zou, X. Zhang and L. Wang, Green Chem., 2015, 17, 4473-4481.

39 X. Zhang, Q. Deng, P. Han, J. Xu, L. Pan, L. Wang and J.-J. Zou, AIChE J., 2017, 63, 680-688.

40 Q. Deng, P. Han, J. Xu, J.-J. Zou, L. Wang and X. Zhang, Chem. Eng. Sci., 2015, 138, 239-243.

41 Q. Deng, J. Xu, P. Han, L. Pan, L. Wang, X. Zhang and J.-J. Zou, Fuel Process. Technol., 2016, 148, 361-366.

42 J. N. Chheda, G. W. Huber and J. A. Dumesic, Angew. Chem., Int. Ed., 2007, 46, 7164-7183.

43 L. Faba, E. Diaz and S. Ordonez, ChemSusChem, 2013, 6, 463473.

44 J. Yang, N. Li, G. Li, W. Wang, A. Wang, X. Wang, Y. Cong and T. Zhang, ChemSusChem, 2013, 6, 1149-1152.

45 J. Yang, N. Li, S. Li, W. Wang, L. Li, A. Wang, X. Wang, Y. Cong and T. Zhang, Green Chem., 2014, 16, 4879-4884.
46 R. E. O'Neill, L. Vanoye, C. De Bellefon and F. Aiouache, Appl. Catal., B, 2014, 144, 46-56.

47 K. A. M. a. R. B. Moore, Chem. Rev., 2004, 104, 4535-4586.

48 R. Weingarten, G. A. Tompsett, W. C. Conner and G. W. Huber, J. Catal., 2011, 279, 174-182.

49 M. Cadenas, R. Bringué, C. Fité, E. Ramírez and F. Cunill, Top. Catal., 2011, 54, 998-1008.

50 J. Jae, G. A. Tompsett, A. J. Foster, K. D. Hammond, S. M. Auerbach, R. F. Lobo and G. W. Huber, J. Catal., 2011, 279, 257-268.

51 D. S. Noyce and W. A. Pryor, J. Am. Chem. Soc., 1955, 77, 1397-1401.

52 S. K. R. Patil, J. Heltzel and C. R. F. Lund, Energy Fuels, 2012, 26, 5281-5293.

53 S. K. R. Patil and C. R. F. Lund, Energy Fuels, 2011, 25, 47454755.

54 I. van Zandvoort, Y. Wang, C. B. Rasrendra, E. R. H. van Eck, P. C. A. Bruijnincx, H. J. Heeres and B. M. Weckhuysen, ChemSusChem, 2013, 6, 1745-1758. 